\title{
The effect of process water salinity on flotation of copper ore from Lubin mining region (SW Poland)
}

\author{
Alicja Bakalarz ${ }^{1}$, Magdalena Duchnowska ${ }^{1}$, and Andrzej Luszczkiewicz ${ }^{1, *}$ \\ ${ }^{1}$ Wroclaw University of Science and Technology, Wybrzeze Wyspianskiego 27, 50-370 Wroclaw, Poland
}

\begin{abstract}
The process water used for the flotation of sedimentary copper ore in ore concentration plants in KGHM Polska Miedz S.A. were characterized. The process water used in the flotation circuits is heavily saline. It contains between 25 and $45 \mathrm{~g} / \mathrm{dm}^{3}$ of soluble components, and the main constituent, in about $75 \%$, is $\mathrm{NaCl}$. Process water used for flotation consists of reclaimed water from the tailing dam and mine water. The effect of process water salinity on the processes of copper flotation from the Lubin mine area was described. The results of laboratory flotation experiments conducted in tap water and in water of different salinity levels were compared. The effect of the salinity of water within specified concentration limits was generally found to be beneficial for upgrading of the examined ore.
\end{abstract}

\section{Introduction}

\subsection{The effect of process water salinity on the flotation processes}

The physicochemical properties of the process water, i.e. its ionic composition and the amount of dissolved substances, are one of the most important factors influencing the course of flotation processes. It is known from industrial practice that the concentration of soluble salts in flotation slurries affects the course of flotation processes. Because of the widespread freshwater shortage in industrial areas, the use of saline water in the flotation process is a necessity. Since the 1930s saline sea water has been used for flotation [1]. Laskowski [2] described the beneficial effect of salts soluble in flotation solutions on the course and effectiveness of flotation. This was, however, mainly related to naturally very hydrophobic minerals and hard coal. In such raw materials there is a 2-3 times increase in flotation rate compared to nonsaline water. Pugh et al [3] groups electrolytes that affect the efficiency of graphite flotation into three groups. Group A electrolytes of small, strongly charged and hydrated cations (divalent and trivalent), such as $\mathrm{MgCl}_{2}$, $\mathrm{CaCl}_{2}, \mathrm{Na}_{2} \mathrm{SO}_{4}, \mathrm{MgSO}_{4}, \mathrm{LiCl}_{3}$ have the most favourable impact. In the presence of these cations, the flotation occurs at a concentration of $0.02 \mathrm{M}$ and reaches the maximum at a concentration of approximately 0.06 to 1.0 M. Group B, comprising $\mathrm{NaCl}, \mathrm{LiCl}, \mathrm{KCl}, \mathrm{CsCl}, \mathrm{NH}_{4} \mathrm{Cl}$, shows the most favourable, however, slightly weaker effects on flotation at concentrations from 0.05 to $0.1 \mathrm{M}$. The last, $\mathrm{C}$ group of electrolytes $\left(\mathrm{NaClO}_{4}, \mathrm{HClO}_{4}, \mathrm{HCl}\right.$, $\mathrm{H}_{2} \mathrm{SO}_{4}, \mathrm{LiClO}_{4}, \mathrm{CH}_{3} \mathrm{COONa}$ ) has a very poor effect on the flotation recovery and effectiveness substantially regardless of the concentration measured to approximately 3.0 M. The effect of the mentioned monoand divalent metal salts in sulphide minerals flotation differs considerably. Many scholars have unambiguously stated that in the case of chalcopyrite monovalent metal salts, e.g. $\mathrm{NaCl}$ and $\mathrm{KCl}$, have a beneficial effect on flotation upgradeability. The presence of calcium and magnesium salts, on the other hand, causes respectively a weak and strong effect of the depression of flotation of this mineral $[4,5]$. Many authors point to the beneficial effect of sulphides flotation in saline water against low mineralization waters, e.g. tap water [6].

Flotation of metal ore in saline water has been the subject of many studies conducted in recent years due to the increasing shortage of freshwater or lack of it in major mining areas, especially of non-ferrous metal ore. The described problems most often concern the use of seawater and, in general, closed circuit water including water recycling from thickening and filtration of the concentrate and, first of all, from the system of processing plant - settling pond of flotation tailing [7]. The quoted authors recommend ongoing monitoring of the physicochemical state of circulating water, e.g. ionic composition, Eh-pH potential, suspended colloidal particles, and the adapting of the technological regime to changing water properties.

The effect of process water salinity on the processes of flotation of ores mined in Lubin Mining Region has been observed since the start of the concentrating plants operation. From the study of Zmudzinski and Lekki [8], analyzed by Karpisz with upgrading curves [9], it results that the artificial addition of $\mathrm{NaCl}$ to tap water up to $100 \mathrm{~g} / \mathrm{dm}^{3}$ has a positive influence on the flotation of carbonate and shale ore, while the addition above $6 \mathrm{~g} / \mathrm{dm}^{3}$ adversely affected the flotation of sandstone ore. In the studies of Kowalska $[10,11]$, the influence of dilution of

\footnotetext{
*Corresponding author: andrzej.luszczkiewicz@pwr.edu.pl
} 
process water of Polkowice Concentrator with low-saline water collected in those days from the Odra River was found to be unfavorable.

The problem of the effect of process water salinity on the flotation process was also recently investigated by Luszczkiewicz and co-workers [12]. The studies have shown that dilution of process water does not alter the results or leads to improvement of flotation efficiency. By contrast, increasing of salt concentration of process water by evaporation results in a significant deterioration of the flotation efficiency. In turn, the purification of process water with the use of activated carbon most often also leads to a deterioration in the selectivity of flotation. The deliberate addition of $\mathrm{NaCl}$ to process water in a very different way influenced the results of flotation. This generally did not change the selectivity of $\mathrm{Cu}$ and $\mathrm{C}_{\text {org }}$ flotation but slightly decreased the flotation selectivity of $\mathrm{Ag}$ and $\mathrm{Pb}$.

\subsection{Water used in technological processes of ore upgrading in KGHM Polska Miedz S.A.}

The process water used in ore upgrading in KGHM Polska Miedz S.A. consists of reclaimed water from the tailing dam which is fed with mine water. The latter significantly differs in the amount of the soluble components in the particular mining areas associated with processing plants. Water circulating in concentrating plants is additionally supplied with soluble components washed out of the treated ores. As a result, water in the flotation circuits of the KGHM Polska Miedz S.A. processing plants is characterized by high content of inorganic salts. According to Luszczkiewicz and others [12], the concentration of soluble components in recycled water from the Zelazny Most tailings dam, which feeds predominantly flotation systems, varies within 23-33 $\mathrm{g} / \mathrm{dm}^{3}$. The recycled water from the "Zelazny Most" pond is mixed with mine water in the processing plants, carrying different amounts of soluble salts, therefore, in different areas of the Concentrator, flotation process water varies and, depending on the region, contains between 20 and $40 \mathrm{~g} / \mathrm{dm}^{3}$ of soluble components (Table 1).

As noted in the study of Luszczkiewicz et al. [13], data from Table 1 show that the ionic product of calcium and sulphate ions is $0.77 \cdot 10^{-3}$ up to $1.2 \cdot 10^{-3}$ and it is significantly higher than the solubility equilibrium product of various forms of calcium sulphate (below $3.1 \cdot 10^{-5}$ ). This means that the KGHM process water is supersaturated with calcium sulphate (gypsum and anhydrite) and precipitation of these substances is expected. This supersaturation is based on the presence of other salts that shift chemical equilibrium and the socalled activity coefficients and thus solubility. The source of sulphate ions, besides gypsum or anhydrite, is also magnesium sulphate. The $\mathrm{MgSO}_{4}$ stoichiometry $\left(\mathrm{SO}_{4}{ }^{2-}=\right.$ $\left.96 \mathrm{~g} / \mathrm{mol}, \mathrm{M}_{\mathrm{Mg}+2}=24.3 \mathrm{~g} / \mathrm{mol}, \mathrm{M}_{\mathrm{MgSO} 4}=120.3 \mathrm{~g} / \mathrm{mol}\right)$ shows that if in process water of the Concentrator is at least $250 \mathrm{mg} / \mathrm{dm}^{3} \mathrm{mg}^{2}$ this is accompanied by about 1000 $\mathrm{mg} / \mathrm{dm}^{3}$ sulphate ions. In turn, the discussed water contains approximately $3000 \mathrm{mg} / \mathrm{dm}^{3} \mathrm{SO}_{4}{ }^{2-}$ ions, i.e. 2000 $\mathrm{mg} / \mathrm{dm}^{3}$ comes from $\mathrm{CaSO}_{4}$ (theoretically approx. 1700 $\left.\mathrm{mg} / \mathrm{dm}^{3}\right)$.

Table 1. Results of determination of the major chemical components of process water of the Lubin, Polkowice and Rudna Concentrators [13].

\begin{tabular}{|c|c|c|c|c|c|}
\hline \multicolumn{2}{|c|}{ Symbol } & unit & Lubin & Polkowice & Rudna \\
\hline \multicolumn{2}{|c|}{$\mathrm{Fe}$} & $\mathrm{mg} / \mathrm{dm}^{3}$ & 0.22 & 0.66 & 0.61 \\
\hline \multicolumn{2}{|c|}{$\mathrm{Cu}$} & $\mathrm{mg} / \mathrm{dm}^{3}$ & 0.202 & 4.80 & 2.02 \\
\hline \multicolumn{2}{|c|}{$\mathrm{Zn}$} & $\mathrm{mg} / \mathrm{dm}^{3}$ & 0.168 & 0.320 & 0.672 \\
\hline \multicolumn{2}{|c|}{$\mathrm{Pb}$} & $\mathrm{mg} / \mathrm{dm}^{3}$ & $<0.005$ & 0.478 & 1.50 \\
\hline \multicolumn{2}{|c|}{ As } & $\mathrm{mg} / \mathrm{dm}^{3}$ & $<0.005$ & 0.038 & $<0,005$ \\
\hline \multirow{2}{*}{\multicolumn{2}{|c|}{$\mathrm{Mg}$}} & $\mathrm{mg} / \mathrm{dm}^{3}$ & 265 & 253 & 121.50 \\
\hline & & $\mathrm{mol} / \mathrm{dm}^{3}$ & 0.011 & 0.010 & 0.005 \\
\hline \multirow{2}{*}{\multicolumn{2}{|c|}{$\mathrm{Ca}$}} & $\mathrm{mg} / \mathrm{dm}^{3}$ & 1325 & 1614 & 994 \\
\hline & & $\mathrm{mol} / \mathrm{dm}^{3}$ & 0.0330 & 0.0403 & 0.0248 \\
\hline \multirow{2}{*}{\multicolumn{2}{|c|}{$\mathrm{Na}$}} & $\mathrm{mg} / \mathrm{dm}^{3}$ & 6162 & 7827 & 12171 \\
\hline & & $\mathrm{mol} / \mathrm{dm}^{3}$ & 0.268 & 0.340 & 0.529 \\
\hline \multirow{2}{*}{\multicolumn{2}{|c|}{$\mathrm{SO}_{4}{ }^{2-}$}} & $\mathrm{mg} / \mathrm{dm}^{3}$ & 2810 & 2829 & 2994 \\
\hline & & $\mathrm{mol} / \mathrm{dm}^{3}$ & 0.0293 & 0.0295 & 0.0312 \\
\hline \multirow{2}{*}{\multicolumn{2}{|c|}{$\mathrm{Cl}^{-}$}} & $\mathrm{mg} / \mathrm{dm}^{3}$ & 11150 & 13438 & 19728 \\
\hline & & $\mathrm{mol} / \mathrm{dm}^{3}$ & 0.315 & 0.379 & 0.556 \\
\hline \multicolumn{2}{|c|}{$\begin{array}{c}\text { Soluble } \\
\text { components }\end{array}$} & $\mathrm{mg} / \mathrm{dm}^{3}$ & 24180 & 29820 & 43450 \\
\hline \multicolumn{2}{|c|}{$\begin{array}{c}\text { Total } \\
\text { suspended } \\
\text { matter }\end{array}$} & $\mathrm{mg} / \mathrm{dm}^{3}$ & 9.0 & 18.0 & 56.0 \\
\hline \multicolumn{2}{|c|}{ Dry residue } & $\mathrm{mg} / \mathrm{dm}^{3}$ & 24440 & 29690 & 41330 \\
\hline \multirow{3}{*}{$\begin{array}{l}\text { Dry } \\
\text { residue }\end{array}$} & $\mathrm{CaO}$ & $\%$ & 4.44 & 4.71 & 3.58 \\
\hline & $\mathrm{MgO}$ & $\%$ & 1.19 & 1.28 & 1.04 \\
\hline & $\mathrm{NaCl}$ & $\%$ & 74.82 & 86.04 & 62.43 \\
\hline \multicolumn{2}{|c|}{$\begin{array}{l}\mathrm{Na}+\mathrm{Cl} \text { in } \\
\text { dissolved } \\
\text { components }\end{array}$} & $\%$ & 71.6 & 71.32 & 73.4 \\
\hline
\end{tabular}

Groundwater (mine water), depending on the area of the deposit and the depth of the mining, varies considerably. Kleczkowski et al. [14] report that the increase in mineralization (dry residue after evaporation) is observed with depth. Mineralization in the mining areas of the deposit in years 2003-2006 in the southern areas ranged from 0.79 to $4.25 \mathrm{~g} / \mathrm{dm}^{3}$ on average $2.12 \mathrm{~g} / \mathrm{dm}^{3}$, while in the northern areas from 22.55 to $328.80 \mathrm{~g} / \mathrm{dm}^{3}$. The average mineralization of water in this area in the region of the deepest mining works is approx. $161 \mathrm{~g} / \mathrm{dm}^{3}$ including concentration of chlorides over $100 \mathrm{~g} / \mathrm{dm}^{3}$. In the NE direction with depth, the mineralization increases even to more than $330 \mathrm{~g} / \mathrm{dm}^{3}$. The increase in mineralization is related to the increase in chlorides, since the concentration of sulphate already at a depth of about $600 \mathrm{~m}$ is stabilized at about $2 \mathrm{~g} / \mathrm{dm}^{3}$. The water in the northern area of the deposit is saline of type $\mathrm{Cl}-\mathrm{Na}-\mathrm{Ca}$, in which the presence of iodides and bromides and significant amounts of iron are found. In the southern areas there is saline of type $\mathrm{SO}_{4}-\mathrm{Cl}-\mathrm{Ca}$ and $\mathrm{SO}_{4}-\mathrm{Cl}-\mathrm{Na}$ [14].

Process water used in flotation in different regions of the concentrating plant differs in composition. This is due to the fact of mixing of recycled water from the tailing dam with mine drainage water, which in the particular 
mining areas varies in both amount and concentration. As shown in Table 1, the salinity considered as the amount of substances dissolved in water varies between 24 and 43 $\mathrm{g} / \mathrm{dm}^{3}$ depending on the Concentrator's connected with the mining area. The dominant components of this water are $\mathrm{Na}^{+}$and $\mathrm{Cl}^{-}$ions, therefore, the main component is sodium chloride, whose share in total water salinity in all three plants is similar, at $71-73 \%$. The calcium and sulphate ions present in the process water are mostly derived from the dissolution of the anhydrite found in the ore. The sulphate concentration is maintained at a constant level of $3 \mathrm{~g} / \mathrm{dm}^{3}$. The source of sulphate ions is also magnesium sulphate.

The analysis of salt content in process water in all three regions of the Concentrator observed over many years shows that chlorine concentration in process water has been steadily increasing [12].

The increase in salinity of flotation water has been observed since the beginning of the development of the Lubin-Glogow Copper Basin (LGOM) deposits. The salinity is systematically increasing from around $6 \mathrm{~g} / \mathrm{dm}^{3}$ of soluble substances in reclaimed water from the settling pond "Gilów" [15] to the present amount of approx. 35$40 \mathrm{~g} / \mathrm{dm}^{3}$. Currently, in the reclaimed water of the "Zelazny Most" tailings dam, compared to data from the late 1960s, the content of soluble components and chloride ions increased approximately fivefold/sixfold and the amount of sulfate ions increased more than one and a half times with a tendency toward equilibrium at approx. $3000 \mathrm{mg} / \mathrm{dm}^{3}$.

\section{Experimental}

\subsection{Research materials and methodology}

The research material was a sample of ore from the Lubin Mine area. The ore sample represented crushed raw feed from current production. It was collected from the Lubin Concentrator's carbonaceous ore stream, directed to the 1st stage of grinding. The sample was crushed in a laboratory jaw crusher to a grain size $<1 \mathrm{~mm}$ and subjected to grinding in a laboratory to a grain size $P_{90}<0.071 \mathrm{~mm}$ (Table 2). The ground ore was the material for flotation experiments. Chemical analyzes showed the following content of balanced components: $0.97 \% \mathrm{Cu}$, 50 g/Mg Ag, $0.99 \% \mathrm{C}_{\text {org }}$.

The composition of process water used in the flotation experiments, taken from the plant technological circuit during the collection of test ore, is summarized in Table 3. Table 3 also contains the composition of tap water used in experiments.

The experiments were performed in a laboratory Mechanobr type flotation machine with $1 \mathrm{dm}^{3}$ cell volume. Standard flotation reagents used in the Lubin Concentrator were used in the experiments: the collector was sodium ethyl and isobutyl xanthate, mixed with Hostaflot LET at 80:20, dosed at $74 \mathrm{~g} / \mathrm{Mg}$ of the ore; a mixture of Corflot with Nasfroth in ratio 40:60 in the amount of $16 \mathrm{~g} / \mathrm{Mg}$ was used as frother.
Table 2. Particle size analysis of feed for flotation experiments.

\begin{tabular}{|c|c|c|c|c|c|c|}
\hline \multirow{2}{*}{$\begin{array}{l}\text { Grain class, } \\
\text { mm }\end{array}$} & \multirow{2}{*}{$\begin{array}{c}\text { Yield, } \\
\gamma, \%\end{array}$} & \multirow{2}{*}{$\begin{array}{c}100-\Sigma \gamma, \\
\%\end{array}$} & \multicolumn{2}{|c|}{$\mathrm{Cu}$} & \multicolumn{2}{|c|}{ Ag } \\
\hline & & & $\lambda, \%$ & $\varepsilon, \%$ & $\begin{array}{c}\lambda \cdot \\
\mathbf{g} / \mathbf{M g}\end{array}$ & $\varepsilon, \%$ \\
\hline$>0.100$ & 2.5 & 100.0 & 0.56 & 1.4 & 60 & 3.1 \\
\hline $0.071 \div 0.100$ & 7.4 & 97.5 & 0.62 & 4.8 & 36 & 5.5 \\
\hline $0.040 \div 0.071$ & 25.0 & 90.1 & 0.93 & 24.2 & 44 & 22.7 \\
\hline $0.020 \div 0.040$ & 21.7 & 65.0 & 1.16 & 26.2 & 40 & 17.9 \\
\hline$<0.020$ & 43.3 & 43.3 & 0.96 & 43.3 & 57 & 50.8 \\
\hline Calculated feed & 100.00 & & 0.96 & 100.0 & 49 & 100.0 \\
\hline Assayed feed & & & 0.97 & & 50 & \\
\hline
\end{tabular}

$\lambda$ - component content in the product, $\%$

$\varepsilon$-component distribution in the product, $\%$

Table 3. Results of chemical analysis of process and tap water used in flotation experiments.

\begin{tabular}{|c|c|c|}
\hline \multirow{2}{*}{ Component } & \multicolumn{2}{|c|}{ Content $\mathrm{mg} / \mathrm{dm}^{3}$} \\
\hline & Process water & Tap water \\
\hline Total iron & $<0.05$ & $<0.02$ \\
\hline Copper & 0.028 & not found \\
\hline Zinc & 0.096 & not found \\
\hline Lead & 0.013 & not found \\
\hline Arsenic & $<0.005$ & not found \\
\hline Magnesium & 394 & 13.3 \\
\hline Calcium & 1687 & 93 \\
\hline Sodium & 8866 & 22.3 \\
\hline Sulphates & 2962 & 105 \\
\hline Nitrates & 35.9 & 17.7 \\
\hline Nitric nitrogen & 8.12 & not found \\
\hline Chlorides & 15295 & 49.8 \\
\hline $\mathrm{CaCO}_{3}$ & 5839 & 288 \\
\hline Soluble components & 32070 & 350 \\
\hline Dry residue & 32320 & \\
\hline
\end{tabular}

The experiments were performed according to the flowsheet shown in Fig. 1. Four series of tests with different types of water were made:

- with natural process water taken in the Lubin Concentrator where the ore material came from (Table 3). This water contained approx. $32 \mathrm{~g} / \mathrm{dm}^{3}$ of dissolved components,

- with process water diluted with tap water in the proportion of $30 \%$ of process water and $70 \%$ of tap water. This water therefore contained approx. $10 \mathrm{~g} / \mathrm{dm}^{3}$ of dissolved components,

- with process water, in which pure sodium chloride was additionally dissolved. The amount added was equal to $100 \%$ of the amount of this salt present in the natural state in process water. The content of $\mathrm{NaCl}$ in the natural state of process water was calculated stoichiometrically assuming that the total $\mathrm{Cl}^{-}$ion is bounded in the form of $\mathrm{NaCl} .18 .4 \mathrm{~g} / \mathrm{dm}^{3}$ of crystalline $\mathrm{NaCl}$ was added to natural process water, resulting in its total content of $43.9 \mathrm{~g} / \mathrm{dm}^{3}$ of soluble components, including $37.8 \mathrm{~g} / \mathrm{dm}^{3}$ of dissolved $\mathrm{NaCl}$,

- with tap water. 


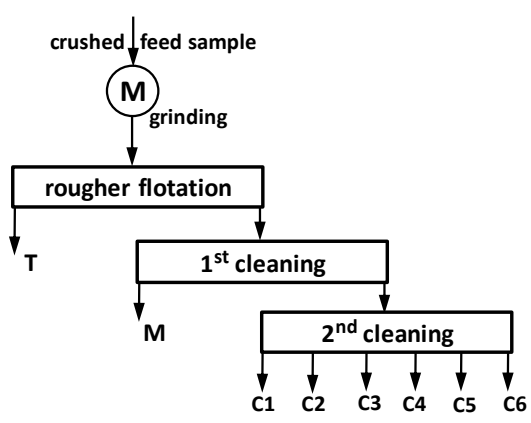

Fig. 1. General flowsheet of flotation experiments.

\subsection{Discussion of results}

Fig. 2-4 show the results of the flotation experiments of the examined ore in the form of recovery-grade and recovery-recovery upgrading curves obtained in various types of water, balanced for copper, silver and organic carbon.
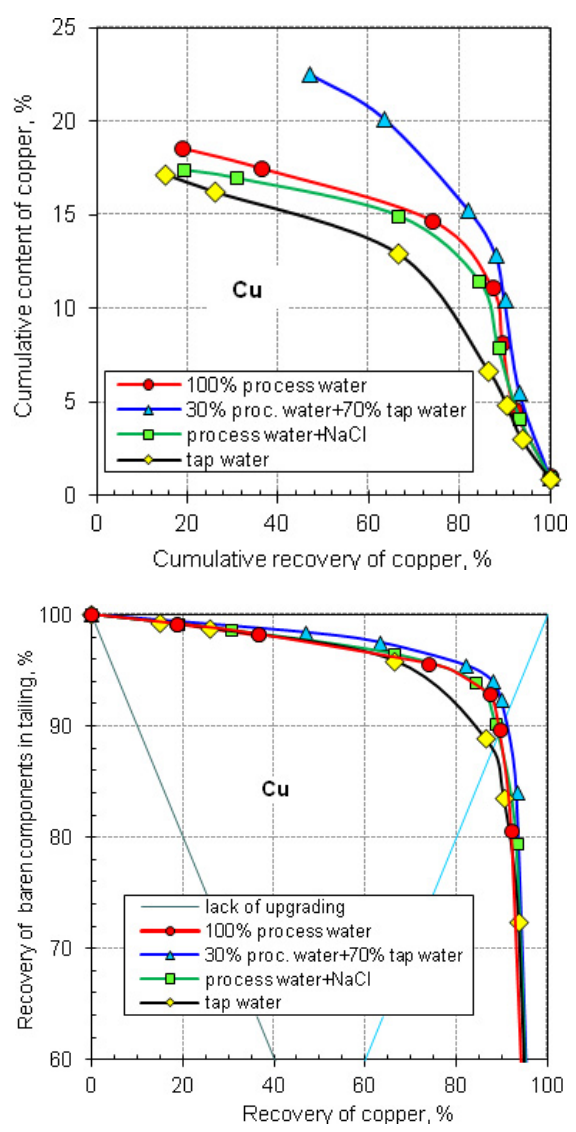

Fig. 2. Results of ore flotation according to $\mathrm{Cu}$ balance in different types of water.
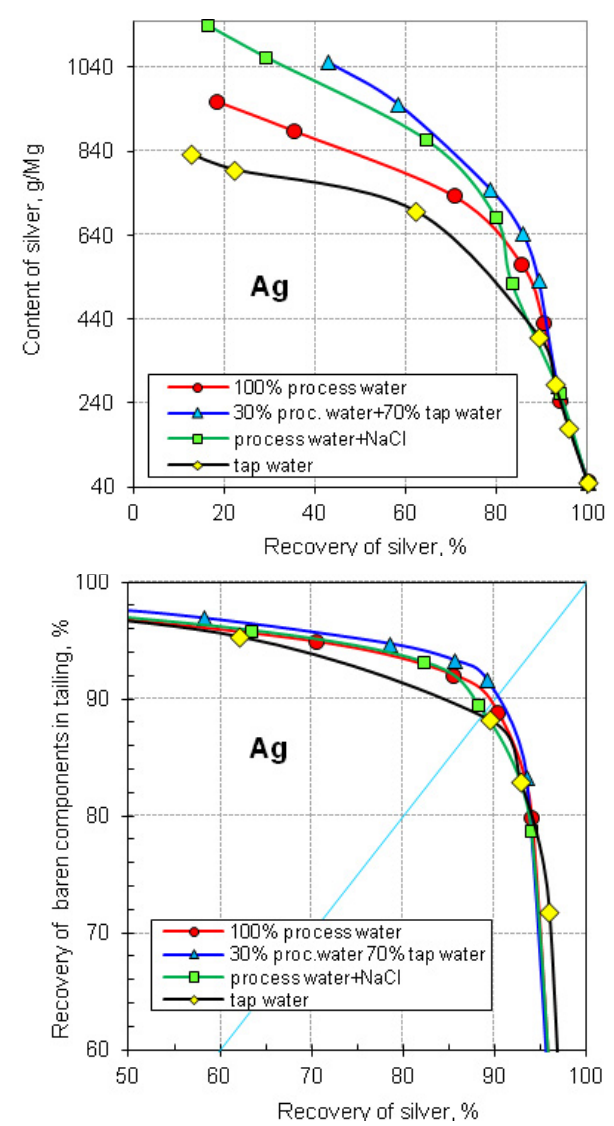

Fig. 3. Results of flotation experiments balanced by silver

Analysis of upgrading curves showed that water salinity has a positive effect on the floatability of all three balanced components. The worst results of the process is observed in the case of tap water. With the increase of salts dissolved in the flotation water $(30 \%$ of the saline process water with $70 \%$ of tap water) used in the tests, the results of upgrading were most favorable in the series of tests described. Flotation in the naturally saline process water was significantly worse than flotation in diluted process water, but significantly better than in tap water. Increasing the salinity of process water by dissolving $\mathrm{NaCl}$ in it, slightly affected the results of flotation according to the $\mathrm{Cu}$ balance (Fig. 2). In contrast, this addition had a better effect on silver upgrading (Fig. 3). By comparing the floatability of copper and silver in all four types of water (Fig. 5), one notices a slightly worse silver upgradeability. With the increase in salinity $(\mathrm{NaCl}$ addition) these differences become smaller.

Upgrading of organic carbon as an unfavorable component in copper concentrates (Fig. 4) shows a downward trend with increasing water salinity in flotation. The strong increase in salinity, however, causes a significant increase in the content of this component in the obtained concentrates. Comparison of the behavior of organic carbon in the analyzed water types (Fig. 5) clearly indicates that this component is the worst upgraded in tap water, and any increase in salinity has a positive effect on its flotation. 

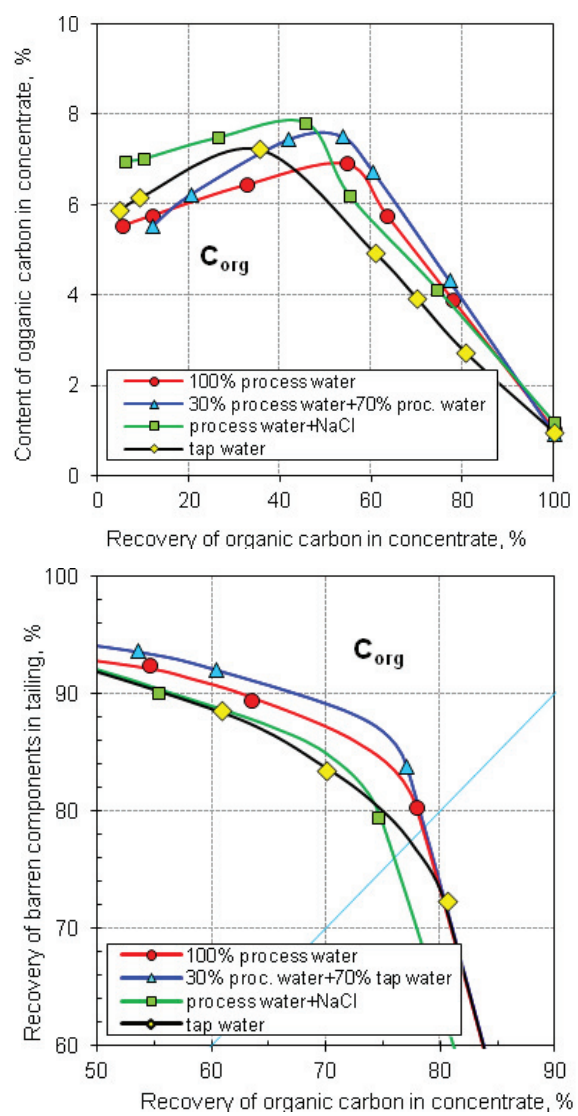

Fig. 4. Results of flotation experiments balanced by organic carbon.

The results of copper ore flotation experiments in flotation water of different salinity levels have been confirmed by numerous literature data on the effect of sea water on the efficiency of upgrading of these ores. The copper ore from the Lubin Concentrator used in experiments is of the polymineral character. The metal carriers in this ore are mainly bornite, chalcopyrite and to a lesser amount chalcocite. Mineralogical analyzes of flotation products indicated a beneficial effect of salinity on the upgrading of chalcopyrite and bornite in the concentrate, whereas chalcocite clearly exhibited poorer floatability. It can be assumed that the mechanism of the beneficial effect of salinity on the flotation of sulphide minerals is in accordance with the literature $[5,6]$. In case of presence of clay minerals in the flotation suspension Zhao and Peng [16] explain the deterioration of water flotation in tap water by the electrochemical impact of mineral surface resulting in easier mulching in tap water on sulphide minerals, especially on chalcocite.
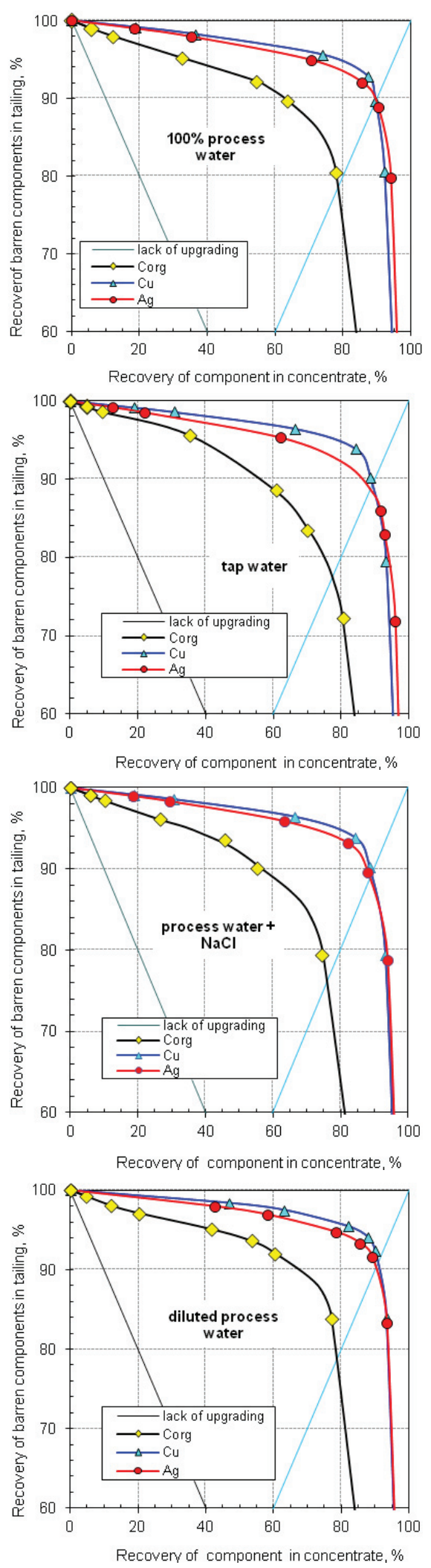

Fig. 5. Comparison of the results of flotation experiments in the analysed types of water. 


\section{Conclusion}

The balances of flotation experiments of copper ore from the Lubin mining region, analyzed in terms of copper, silver and organic carbon indicate the beneficial effect of the salinity of the water used on the upgradeability of the balanced components. Dilution of process water with tap water in a ratio of 70 to $30 \%$ resulted in the most favorable flotation conditions for all balanced components: copper, silver and organic carbon. Flotation in process water indicates more favorable flotation effects of all balanced components compared to flotation in tap water.

When comparing the flotability of copper and silver in all four analysed types of water, a slightly weaker silver upgradeability is noted. With the increase in salinity $(\mathrm{NaCl}$ added at $100 \%$ of its original amount in process water), these differences become smaller. On the other hand, the disadvantage of organic carbon is that it is poorly upgraded in tap water, and any increase in salinity has a positive effect on its flotation.

The article was co-financed by funds of statutory research no. 0402/0161/16 carried out at the Faculty of Geoengineering, Mining and Geology of Wroclaw University of Science and Technology.

\section{References}

1. S. Castro, I. Venegas, A. Landero, J.S. Laskowski, Frothing in seawater flotation systems. In Proceedings of XXV International Mineral Processing Congress, Brisbane, Australia. The Australasian Institute of Mining and Metallurgy, 4039-4047 (2010)

2. J. Laskowski, Chemia fizyczna $w$ procesach mechanicznej przeróbki kopalin (1969)

3. R.J. Pugh, P. Weissenborn, O. Paulson, 1997. Int. J. Miner. Process. 51(1-4), 125-138 (1997)

4. T. Hirajima, WSE Suyantara, O. Ichikawa, A.M. Elmahdy, H. Miki, K. Sasaki, 2016. Miner. Eng. 96, 83-93 (2016)

5. F. Rao, I. Lázaro, L.A. Ibarra, Miner. Process. Extr. Metall. Rev. 126(3), 139-145 (2017)

6. F. Ikumapayi, K.H. Rao, 2015. Miner. Process. Extr. Metall. Rev. 36(1), 45-64 (2015)
7. G. Levay, R.S.C. Smart, W.M. Sinner, J. South. Afr. Inst. Min. Metall. 101(2), 69-75 (2001)

8. K. Zmudziński, J. Lekki, Badania nad wplywem składu wód kopalnianych $w$ legnicko- głogowskim okręgu miedziowym na flotację rud miedzi. Report No. 1216/67, Department of Ore Processing, Institute of Non-Ferrous Metals, Gliwice (1967)

9. A. Karpisz, Wplyw parametrów fizykochemicznych wody technologicznej na flotowalność rud miedzi. Diploma thesis, Faculty of Geoengineering, Mining and Geology, Wroclaw University of Sience and Technology, Wroclaw (2010)

10. M. Kowalska, Badanie wplywu wody z Odry na wyniki flotacji rudy polkowickiej. ZD Cuprum Report in Lubin No. 3/TP/76 (1976)

11. M. Kowalska, Wpływ jakości wody technologicznej na wskaźniki wzbogacania w ZG ZWR Rudna. ZD Cuprum report in Lubin (1978)

12. A. Luszczkiewicz, J. Drzymala, T. Henc, $\dot{Z}$. Konopacka, M. Duchnowska, Określenie wpływu związków chemicznych zawartych $w$ wodach przemystowych na proces wzbogacania w O/ZWR. Study Report: Report No. S-42/2011, Wroclaw University of Science and Technology, Institute of Mining (2011)

13. A. Luszczkiewicz, A. Konieczny, E. Kasinska-Pilut, J. Drzymala, Charakterystyka wód stosowanych do flotacji w O/ZWR KGHM Polska Miedź S.A. Materiały III Polskiego Kongresu Górniczego, Mineralurgia i wykorzystanie surowców mineralnych, Drzymała J., Kowalczuk P.B. (eds), 14-16 September 2015, Wrocław, 28-34 (2015)

14. A. Kleczkowski, S. Downorowicz, W. Zimny, R. Becker, KGHM Polska Miedź S.A. Monograph, multiple authors, eds A. Piestrzyński, A. Banaszak, M. Zalewska-Kusmierczyk, KGHM Cuprum sp. z o.o. CBR, Wrocław, 133-138 (2007)

15. L. Dobrowolski, B. Nowakowska, Ustalenie przyczyn obniżania się wskaźnika zużycia odczynnika pianotwórczego $w$ procesie wzbogacania rudy miedzi w ZPM w Lubinie. Report No TGE / TW / 69, part. 2, KGHM Experimental Plant in Lubin (1969)

16. S. Zhao, Y. Peng, Miner. Eng. 66, 152-156 (2014) 